\title{
A Comparison of the Perceptions of Secondary School Teachers' Satisfaction about their Jobs
}

\author{
Asif Iqbal ${ }^{1}$, Muhammad Shabbir Ali ${ }^{2}$, \\ Muhammad Saeed Akhtar ${ }^{3}$, Shehzad Ahmed ${ }^{4}$ \\ 1. Assistant Professor (Ph. D. Education), GC University Faisalabad, Pakistan \\ 2. Assistant Professor (Ph. D. Education), GC University Faisalabad, Pakistan \\ 3. Professor of Education, University of the Punjab Lahore, Pakistan \\ 4. Assistant Professor (Ph. D. Education), GC University Faisalabad, Pakistan
}

\begin{abstract}
Job satisfaction is the key aspect of human nature. It is assumed that teachers show less satisfaction than any other organization in developing countries like Pakistan. This study compares the level of job satisfaction between male and female secondary school teachers. Six facets of job satisfaction were developed to compare gender, age, teaching experience, and location of the school with teachers' job satisfaction. The population comprises all public sector secondary school teachers working in district Lahore, Pakistan. Three hundred and twenty two secondary school teachers were randomly selected from sixty public sector secondary schools. Data were collected personally. Job Satisfaction Scale for Teachers (JSST) was used for this purpose. One way ANOVA and t-test were applied. The results are interpreted in the context of Pakistan. Findings of the study suggested that female teachers were more satisfied with work and supervision aspects of job as compared with male teachers. No significant difference was found in the job satisfaction between science \& arts and urban $\&$ rural school teachers. Age and work experience did not explore the job satisfaction difference in teachers. Further studied may be conducted to explore the impact of job satisfaction on students achievement. Based on the findings recommendations are presented.
\end{abstract}

Key Words: Public sector, Job satisfaction, secondary school level

\section{INTRODUCTION}

According to Koustelios (2001), the study of job satisfaction is a major research activity throughout world in all walks of organizational life including education. More of the work is done in business and industry, however, a reasonable number of studies have also been conducted in the field of education throughout world ${ }^{111}$. According to Chambers (1999), Every individual needs job to fulfill basic needs. It shares in strengthening the financial basis for individuals' lifestyle. Therefore the job satisfaction is a most interesting field for many researchers to study work attitude in workers. Due to better performance shown by satisfied workers, it is the top priority of all organizations to achieve the desired goals by increasing their satisfaction ${ }^{|2|}$. It is also important due to its significance with the physical and mental wellbeing of workers. It is closely related to behaviors such as productivity, absenteeism, and turnover. Besides its humanitarian value it makes the economic basis to get maximum financial remuneration. Research focusing specially on job satisfaction for secondary school teachers identified several indicators of satisfaction and dissatisfaction. Job satisfaction is also associated with teacher quality, organizational commitment and performance with reference to scholastic achievement, attitude of students, tutors turnover, and executive performance (Mathieu, 1991 ${ }^{|3|}$; Ostroff, $1992^{|4|}$ ). It is assumed that job satisfaction has dual role as a contributing aspect to commitment and as a prevailing variable that mediates the demographic and organizational determinants with commitment (Mueller, Boyer, Price, \& Iverson, 1994 Price, $1997^{(6)}$ ).

\section{REVIEW OF RELATED LITERATURE}

Job satisfaction is a pleasurable state resulting from the judgment of workers' job experiences (Akhtar, $\left.1994^{|7|}, 2000^{|8|}, 2010^{|9|}\right)$. Teacher's job satisfaction is the satisfaction of teachers while teaching and the perceived relationship between the wants and offering to a teacher (Zambylas \& Papanastasiou, 2004 ${ }^{|10|}$ ).

Job satisfaction has been the burning issue for the researchers throughout the research history. Today all over the world maximum researches have been conducted on this single topic. Improving the quality of work and quantity of products, efforts are being made with minimum input to get maximum output by satisfying the employees on job. Mechanical tools and equipments are not a guarantee for better products. It is only the employees that make the significant difference. This study investigates only the specific variables. They are gender, age, teaching experience, and the location of school. So their brief empirical review is as under: 


\subsection{Gender}

Gender has been the part and parcel of research studies conducted on job satisfaction. However, the association of gender and job satisfaction is inconsistent. Some studies report that women have higher level of job satisfaction than their male peers across most worksites (Lambert, Hogan, Barton, \& Lubbock, $2001^{111}$; Ma \& MacMillan, $\left.1999^{|12|}\right)$. As concerned with teaching profession, survey reveals that female employees and teachers showed higher level of job satisfaction than males (Watson, Hatton, Squires, \& Soliman, 1991 ${ }^{|13|}$ ). Satisfied teachers always ready to extend extra effort in working with students and parents to provide positive results. A study conducted by Al-Mashaan (2003), male employees report higher level of job satisfaction than females due to better employment chances and promotion opportunities ${ }^{114}$. Few studies claimed that men and women show parallel satisfaction (Clark, Oswald, \& Warr, $\left.1996^{151}\right)$. Women due to lower expectations tend to satisfied easily at work (Witt \& Nye, $\left.1992^{166}\right)$. Male teachers attach more importance to career than females hence they show less satisfaction (Kremer-Hayton \& Goldstein, $1990^{1171}$ ).

\subsection{Age}

As revealed from several studies conducted in various organizations age has a positive relationship with job satisfaction (Chambers, 1999 $9^{121}$; Cramer, 1993 $3^{1181}$; Robbins, 2001 ${ }^{1191}$; Siu, Spector, Cooper, \& Donald, $2001^{1201}$; Staw, 1995 ${ }^{121 \mid}$; Tolbert \& Moen, $\left.1998^{1221}\right)$. Also the studies of Blood, Ridenour, Thomas, Qualls, \& Hammer (2002) found that job satisfaction increases with age and work experiences ${ }^{1231}$. Young teachers easily leave the profession than older ones (Ingersoll, 2001) ${ }^{124 \mid}$. Workers with long experience having low expectations to their jobs are more comfortable and tolerant (Spector, 1997) ${ }^{1251}$. Many studies revealed (Begley \& Czajka, $1993^{1261}$; Hodson, 1997 $7^{1271}$; Oshagbemi, 2000 ${ }^{1281}$; Spector, 1997 ${ }^{1251}$ ) that older workers are more satisfied than younger ones. Literature further reveals that older workers tend to be happier with their jobs, have lower turnover rates, and miss fewer working days (Naceur \& Fook, 2001) ${ }^{|29|}$.

\subsection{Tenure}

Tenure is experience of teachers spending in teaching profession. Teachers with greater experience in education show high satisfaction with their professional role than less experienced colleagues (Akhtar, 2000 ${ }^{|8|}$; Sari, $\left.2004^{\mid 301}\right)$. Teachers' professional maturity and experience made them satisfied with students' interaction and resources than novice teachers. Experienced teachers become more confident in dealing with students and parents. Also, experienced teachers may enjoy the privilege of utilizing better facilities and more resources at school because of their seniority. Brown (2005) explored a positive relationship between tenure and job satisfaction ${ }^{131}$.

\subsection{Work location}

Location is the place where the workers spend working hours. With regard to school location, rural teachers were found to be less satisfied than suburban teachers (Ruhl- Smith, 1991) ${ }^{132 \mid}$. Teachers of urban schools found more responsible and sincere to their job and are more satisfied than the rural school teachers because of infrastructure (Tasnim, 2006) ${ }^{1331}$. Researchers have investigated higher levels of job satisfaction in urban educational professionals when compared with rural settings (Arnold, Seekins, \& Nelson, $1997^{1344}$; Finley, $1991^{\mid 35}$ ). In urban areas workers often have more job opportunities, better schools, conveyance facilities, better salary, higher prestige, and greater opportunities for spousal employment. On the other hand, rural settings and smaller communities can provide family-oriented settings, lower crime rates, recreational access and enhanced quality of life. The most commonly mentioned disadvantages to rural settings have been professional isolation and lack of opportunity for professional development. However, recent advancements in telecommunications and interactive networking through the internet will decrease feelings of isolation and improve rural job satisfaction levels in the future (Worrell, 2004) ${ }^{|36|}$. Overall job satisfaction of teachers who stayed in one institution improved significantly with teaching experience, unlike those who hopped from one institution to the other. Furthermore, the levels of overall job satisfaction of those who remain in one institution were, after the first ten years, consistently higher than the corresponding levels of job satisfaction of workers who changed their institutions (Oshagbemi, 2000) ${ }^{1281}$.

School prestige and working conditions were found the best predictors for job satisfaction of teachers in Pakistan. Principals leadership style and peer relationships were the next significant predictors. Leadership style in schools is generally positive towards teachers. Pakistani teachers like teaching profession. Teachers are dissatisfied with school location and about two-third of teachers affirm that they have low status in the society $\left(\right.$ Saeed, 1997) ${ }^{1371}$.

\section{OBJECTIVES OF THE STUDY}

The major objective of the study was to explore teachers' satisfaction working in public sector secondary schools in Lahore district. 


\section{NULL HYPOTHESIS}

Ho1. There is no significant difference between the job satisfaction of male and female secondary school teachers.

Ho2. There is no significant impact of teaching subjects on the job satisfaction level of male and female secondary school teachers.

Ho3. There is no significant impact of school location on the job satisfaction level of male and female secondary school teachers.

Ho4. There is no significant difference impact of age groups on the job satisfaction level between male and female secondary school teachers.

Ho5. There is no significant impact of teaching experience on the job satisfaction level of male and female secondary school teachers.

\section{POPULATION OF THE STUDY}

The population for this study comprised of 272 public sector secondary schools of Lahore district in Pakistan. The list of schools was obtained from the District Education Officer (SE) Lahore. There are 2129 Secondary School Teachers (SSTs) of which 1250 male and 879 female teachers working in this District. Sixty (22\%) schools were randomly selected as sample. Three hundred and twenty two teachers from sixty schools participated voluntarily in the research of which 170 were male teachers and 152 female teachers.

\section{METHODOLOGY}

A survey was conducted to collect the questionnaires personally by the researcher. Teachers were selected randomly. One way ANOVA and t-test were applied to analyze the data. The results were interpreted on the basis of findings.

\section{RESULTS}

Ho1. There is no significant difference between the job satisfaction of male and female secondary school teachers.

Results of independent sample t-test that was implemented with the purpose of testing whether there are meaningful differences between male and female teachers in terms of pay, work, promotion, colleagues, work conditions, and supervision variables are given in table 1.

Table 1

The t-test Results According to Gender

\begin{tabular}{|c|c|c|c|c|c|c|c|}
\hline Variables & Gender & $\mathbf{N}$ & $\mathbf{X}$ & SD & $D F$ & t-value & Sig. \\
\hline Pay & Male & 172 & 23.18 & 3.47 & 320 & -2.015 & .220 \\
\hline Work & $\begin{array}{l}\text { Male } \\
\text { Female }\end{array}$ & $\begin{array}{l}172 \\
150\end{array}$ & $\begin{array}{l}49.63 \\
51.28\end{array}$ & $\begin{array}{l}4.79 \\
4.15\end{array}$ & 320 & -3.282 & $.011 *$ \\
\hline Promotion & $\begin{array}{l}\text { Male } \\
\text { Female }\end{array}$ & $\begin{array}{l}172 \\
150\end{array}$ & $\begin{array}{l}24.18 \\
24.26\end{array}$ & $\begin{array}{l}3.21 \\
3.49\end{array}$ & 320 & -.198 & .862 \\
\hline Work Group & $\begin{array}{l}\text { Male } \\
\text { Female }\end{array}$ & $\begin{array}{l}172 \\
150 \\
\end{array}$ & $\begin{array}{l}22.03 \\
22.67\end{array}$ & $\begin{array}{l}2.46 \\
2.32\end{array}$ & 320 & -2.383 & .941 \\
\hline $\begin{array}{l}\text { Work } \\
\text { Conditions }\end{array}$ & $\begin{array}{l}\text { Male } \\
\text { Female }\end{array}$ & $\begin{array}{l}172 \\
150\end{array}$ & $\begin{array}{l}47.11 \\
49.08\end{array}$ & $\begin{array}{l}5.92 \\
6.00\end{array}$ & 320 & -2.957 & .701 \\
\hline Supervision & $\begin{array}{l}\text { Male } \\
\text { Female }\end{array}$ & $\begin{array}{l}172 \\
150\end{array}$ & $\begin{array}{l}38.98 \\
41.36\end{array}$ & $\begin{array}{l}6.15 \\
4.79\end{array}$ & 320 & -3.814 & $.004 *$ \\
\hline
\end{tabular}

${ }^{*} \mathrm{P}<.05$

Table 1 demonstrates that most of the variables did not show any significant difference with respect to gender. However, there is a meaningful difference exists in the averages in terms of work and supervision. On work and supervision factors female teachers show higher job satisfaction than males. So, it is said that female teachers were more satisfied in work and supervision aspects as compared with male teachers.

Ho2. There is no significant impact of teaching subjects on the job satisfaction level of male and female secondary school teachers.

Result of independent sample t-test that was implemented with the purpose of testing whether there are meaningful differences between averages of teaching subjects which are given in table 2 . 
Table 2

The t-test Results According to Teacher Category Variable

\begin{tabular}{|c|c|c|c|c|c|c|c|}
\hline Variables & Category & $\mathbf{N}$ & $\mathbf{X}$ & SD & $D F$ & t-value & Sig. \\
\hline \multirow{2}{*}{ Pay } & SST Science & 119 & 23.46 & 3.32 & \multirow{2}{*}{320} & \multirow{2}{*}{-.316} & \multirow{2}{*}{.951} \\
\hline & SST Arts & 203 & 23.58 & 3.44 & & & \\
\hline \multirow{2}{*}{ Work } & SST Science & 119 & 50.26 & 4.14 & \multirow{2}{*}{320} & \multirow{2}{*}{-.404} & \multirow{2}{*}{.340} \\
\hline & SST Arts & 203 & 50.48 & 4.82 & & & \\
\hline \multirow{2}{*}{ Promotion } & SST Science & 119 & 24.19 & 3.09 & \multirow{2}{*}{320} & \multirow{2}{*}{-.112} & \multirow{2}{*}{.422} \\
\hline & SST Arts & 203 & 24.23 & 3.48 & & & \\
\hline \multirow{2}{*}{ Work Group } & SST Science & 119 & 22.10 & 2.43 & \multirow{2}{*}{320} & \multirow{2}{*}{-1.270} & \multirow{2}{*}{.540} \\
\hline & SST Arts & 203 & 22.46 & 2.39 & & & \\
\hline \multirow{2}{*}{$\begin{array}{l}\text { Work } \\
\text { Conditions }\end{array}$} & SST Science & 119 & 47.75 & 4.92 & \multirow{2}{*}{320} & \multirow{2}{*}{-.618} & \multirow{2}{*}{.183} \\
\hline & SST Arts & 203 & 48.18 & 6.60 & & & \\
\hline \multirow{2}{*}{ Supervision } & SST Science & 119 & 39.85 & 5.29 & \multirow{2}{*}{320} & \multirow{2}{*}{-.570} & \multirow{2}{*}{. .523} \\
\hline & SST Arts & 203 & 40.23 & 5.90 & & & \\
\hline
\end{tabular}

Table 2 revealed no significant difference between average scores in terms of pay, work, promotion, work group, work conditions, and supervision variables. It is concluded that teachers teaching science and arts subjects did not show any significant difference in their job satisfaction.

Ho3. There is no significant impact of school location on the job satisfaction level of male and female secondary school teachers.

Result of independent sample t-test that was implemented with the purpose of testing whether there are meaningful differences between averages with respect to school location are given in table 3 .

Table 3

The t-test Results According to School Location Variable

\begin{tabular}{|c|c|c|c|c|c|c|c|}
\hline Variables & School & $\mathbf{N}$ & $\mathbf{X}$ & SD & $D F$ & t-value & Sig. \\
\hline \multirow{2}{*}{ Pay } & Urban & 217 & 23.76 & 3.38 & \multirow{2}{*}{320} & \multirow{2}{*}{1.747} & \multirow{2}{*}{.542} \\
\hline & Rural & 105 & 23.06 & 3.38 & & & \\
\hline \multirow{2}{*}{ Work } & Urban & 217 & 50.48 & 4.68 & \multirow{2}{*}{320} & \multirow{2}{*}{.451} & \multirow{2}{*}{.141} \\
\hline & Rural & 105 & 50.23 & 4.37 & & & \\
\hline \multirow{2}{*}{ Promotion } & Urban & 217 & 24.32 & 3.48 & \multirow{2}{*}{320} & \multirow{2}{*}{.824} & \multirow{2}{*}{.069} \\
\hline & Rural & 105 & 24.00 & 3.02 & & & \\
\hline \multirow{2}{*}{ Work Group } & Urban & 217 & 22.39 & 2.46 & \multirow{2}{*}{320} & \multirow{2}{*}{.683} & \multirow{2}{*}{.292} \\
\hline & Rural & 105 & 22.20 & 2.32 & & & \\
\hline \multirow{2}{*}{$\begin{array}{l}\text { Work } \\
\text { Conditions }\end{array}$} & Urban & 217 & 48.17 & 6.04 & \multirow{2}{*}{320} & \multirow{2}{*}{.609} & \multirow{2}{*}{.607} \\
\hline & Rural & 105 & 47.73 & 6.01 & & & \\
\hline \multirow{2}{*}{ Supervision } & Urban & 217 & 40.09 & 5.88 & \multirow{2}{*}{320} & \multirow{2}{*}{.016} & \multirow{2}{*}{.220} \\
\hline & Rural & 105 & 40.08 & 5.27 & & & \\
\hline
\end{tabular}

According to table 3, there is no meaningful difference between average scores in terms of pay, work, promotion, work group, working conditions, and supervision variables. It is found that teachers working in urban and rural areas did not show any significant difference in their job satisfaction.

Ho4. There is no significant difference impact of age groups on the job satisfaction level between male and female secondary school teachers.

Result of ANOVA that was implemented with the purpose of testing whether there are meaningful differences between averages regarding the age variables are given in table 4 .

Table 4

The One Way ANOVA Results According to Age Variable

\begin{tabular}{llllllll}
\hline Variables & $\begin{array}{l}\text { Source } \\
\text { variables }\end{array}$ & $\begin{array}{l}\text { Some of } \\
\text { Square }\end{array}$ & $\boldsymbol{d} f$ & $\begin{array}{l}\text { Mean } \\
\text { Square }\end{array}$ & F & Sig. & Turkey HSD \\
\hline \multirow{4}{*}{ Pay } & Between & 40.614 & 3 & 13.538 & & & \\
& Groups & 3659.361 & 318 & 11.507 & 1.176 & .319 \\
& With in Groups & 3699.975 & 321 & & & & \\
Total & Between & 28.278 & 3 & 9.426 & .448 & .719 \\
\hline \multirow{2}{*}{ Work } & Groups & 6695.237 & 318 & 21.054 & & \\
\hline
\end{tabular}


A Comparison of the Perceptions of Secondary School Teachers' Satisfaction about their Jobs

\begin{tabular}{|c|c|c|c|c|c|c|}
\hline & $\begin{array}{l}\text { With in Groups } \\
\text { Total }\end{array}$ & 6723.516 & 321 & & & \\
\hline Promotion & $\begin{array}{l}\text { Between } \\
\text { Groups } \\
\text { With in Groups } \\
\text { Total }\end{array}$ & $\begin{array}{l}9.100 \\
3572.245 \\
3581.345\end{array}$ & $\begin{array}{l}3 \\
318 \\
321\end{array}$ & $\begin{array}{l}3.033 \\
11.233\end{array}$ & .270 & .847 \\
\hline Work Group & $\begin{array}{l}\text { Between } \\
\text { Groups } \\
\text { With in Groups } \\
\text { Total }\end{array}$ & $\begin{array}{l}26.840 \\
1846.604 \\
1873.444\end{array}$ & $\begin{array}{l}3 \\
318 \\
321\end{array}$ & $\begin{array}{l}8.947 \\
5.708\end{array}$ & 1.541 & .204 \\
\hline Work Condition & $\begin{array}{l}\text { Between } \\
\text { Groups } \\
\text { With in Groups } \\
\text { Total }\end{array}$ & $\begin{array}{l}166.942 \\
11515.806 \\
11682.848\end{array}$ & $\begin{array}{l}3 \\
318 \\
321\end{array}$ & $\begin{array}{l}55.647 \\
36.213\end{array}$ & 1.537 & .205 \\
\hline Supervision & $\begin{array}{l}\text { Between } \\
\text { Groups } \\
\text { With in Groups } \\
\text { Total }\end{array}$ & $\begin{array}{l}53.021 \\
10312.184 \\
10365.205\end{array}$ & $\begin{array}{l}3 \\
318 \\
321\end{array}$ & $\begin{array}{l}17.674 \\
32.428\end{array}$ & .545 & .652 \\
\hline
\end{tabular}

According to table 4, there is no meaningful difference between averages in terms of pay, work, promotion, work group, work conditions and supervision variables.

Ho5. There is no significant impact of teaching experience on the job satisfaction level of male and female secondary school teachers.

Result of ANOVA that was implemented with the purpose of testing whether there are meaningful impact of teaching experience on job satisfaction are given in table 5.

Table 5

The One Way ANOVA Results According to Experience Variables

\begin{tabular}{|c|c|c|c|c|c|c|c|}
\hline Variables & $\begin{array}{l}\text { Source of } \\
\text { variables }\end{array}$ & $\begin{array}{l}\text { Some of } \\
\text { Square }\end{array}$ & $d f$ & $\begin{array}{l}\text { Mean } \\
\text { Square }\end{array}$ & $\mathbf{F}$ & Sig. & Turkey HSD \\
\hline Pay & $\begin{array}{l}\text { Between } \\
\text { Groups } \\
\text { With in Groups } \\
\text { Total }\end{array}$ & $\begin{array}{l}39.941 \\
3660.034 \\
3699.975\end{array}$ & $\begin{array}{l}2 \\
319 \\
321\end{array}$ & $\begin{array}{l}19.971 \\
11.473\end{array}$ & 1.741 & .177 & \\
\hline Work & $\begin{array}{l}\text { Between } \\
\text { Groups } \\
\text { With in Groups } \\
\text { Total }\end{array}$ & $\begin{array}{l}23.300 \\
6700.216 \\
6723.516\end{array}$ & $\begin{array}{l}2 \\
319 \\
321\end{array}$ & $\begin{array}{l}11.650 \\
21.004\end{array}$ & .555 & .575 & \\
\hline Promotion & $\begin{array}{l}\text { Between } \\
\text { Groups } \\
\text { With in Groups } \\
\text { Total }\end{array}$ & $\begin{array}{l}5.958 \\
3575.387 \\
3581.345\end{array}$ & $\begin{array}{l}2 \\
319 \\
321\end{array}$ & $\begin{array}{l}2.979 \\
11.208\end{array}$ & .266 & .767 & \\
\hline Work Group & $\begin{array}{l}\text { Between } \\
\text { Groups } \\
\text { With in Groups } \\
\text { Total }\end{array}$ & $\begin{array}{l}37.307 \\
1836.137 \\
1873.444\end{array}$ & $\begin{array}{l}2 \\
319 \\
321\end{array}$ & $\begin{array}{l}18.653 \\
5.756\end{array}$ & 3.241 & $.040^{*}$ & \\
\hline Work Condition & $\begin{array}{l}\text { Between } \\
\text { Groups } \\
\text { With in Groups } \\
\text { Total }\end{array}$ & $\begin{array}{l}141.077 \\
11541.672 \\
11682.748\end{array}$ & $\begin{array}{l}2 \\
319 \\
321\end{array}$ & $\begin{array}{l}70.538 \\
36.181\end{array}$ & 1.950 & .144 & \\
\hline Supervision & $\begin{array}{l}\text { Between } \\
\text { Groups } \\
\text { With in Groups } \\
\text { Total }\end{array}$ & $\begin{array}{l}19.920 \\
10345.285 \\
10365.205\end{array}$ & $\begin{array}{l}2 \\
319 \\
321\end{array}$ & $\begin{array}{l}9.960 \\
32.430\end{array}$ & .307 & .736 & \\
\hline Over all JS & $\begin{array}{l}\text { Between } \\
\text { Groups } \\
\text { With in Groups } \\
\text { Total }\end{array}$ & $\begin{array}{l}512.060 \\
76418.176 \\
76930.236\end{array}$ & $\begin{array}{l}2 \\
319 \\
321\end{array}$ & $\begin{array}{l}256.030 \\
239.555\end{array}$ & 1.069 & .345 & \\
\hline
\end{tabular}


${ }^{*} \mathrm{P}<.05$

According to table 5, there is no meaningful difference between averages in terms of pay, work, promotion, work conditions, and supervision variables. However, work group shows a significant difference.

\section{CONCLUSION}

This study examines demographic variables related to gender in developing countries like Pakistan. Results of the study indicate that female teachers were more satisfied with work and supervision aspects of work as compared with males. Age and experience has no effect on job satisfaction. Arts and science teachers both were equally satisfied.

\section{DISCUSSION}

Male and female teachers did not show any significant difference of job satisfaction. However, there is meaningful difference exists in the averages in terms of work and supervision and female teachers were more satisfied. It may be justified that female teachers work with more devotion and obey their heads. Prior research evidences are in favour of women satisfaction than males across most worksites (Lambert, et al., 2001 ${ }^{1111}$; Ma \& MacMillan, 1999 ${ }^{\mid 121}$; Watson, et al., $\left.1991^{131}\right)$. It is contrary to many studies that male workers satisfied toward their job while many studies did not found any difference (Al-Mashaan, 2003) ${ }^{|14|}$. Some studies report equal levels of satisfaction (Clark, et al., 1996) ${ }^{|15|}$. This finding also supports the study of Witt and Nye (1992) due to lower expectations and more satisfaction at work by females ${ }^{|16|}$. The less satisfaction of male teachers may be justified with the study of Kremer-Hayton and Goldstein (1990) due to more importance to career by the male teachers ${ }^{\mid 171}$.

Science and arts teachers show equal level of job satisfaction. The reason might be that once entering in the profession teaching subjects are not the matter of satisfaction and dissatisfaction. Teachers teaching science and arts subjects are not given proper credit monetarily. Both have to spent equal hours at school. There is no meaningful difference between average scores in terms of pay, work, promotion, work group, working conditions, and supervision variables. It is found that teachers working in urban and rural areas did not show any significant difference in their job satisfaction. Teachers prefer to enter in the profession regardless of work site location. It is contrary to many studies that are in favor with teachers' satisfaction in urban areas (Ruhl- Smith, $1991^{|32|}$; Tasnim, 2006 ${ }^{|33|}$; Arnold, et al., 1997 ${ }^{|34|}$; Finley, $1991^{|35|}$ ).

Age has no impact on job satisfaction. It means that job satisfaction of teachers did not increase or decrease with the passage of time. While many studies show positive relationship between age and job satisfaction (Chambers, 1999 ; Cramer, 1993 ${ }^{118 \mid}$; Robbins, 2003 $3^{\mid 191}$; Siu, et al., 2001 ${ }^{1201}$; Staw, 1995 ${ }^{121}$; Tolbert \& Moen, $1998^{|22|}$ ), and work experiences (Blood, et al., 2002 ${ }^{231}$ ). On the other hand, evidences show that it is easier for novice teachers to quit the profession than older ones (Ingersoll, 2001 241 ). They gain experience with age and minimized their expectations, so they prefer to continue (Spector, 1997) ${ }^{|25|}$. Researches also favour the older workers satisfaction toward the job as compared with younger workers (Begley \& Czajka, 1993 ${ }^{126}$; Hodson, $1997^{127}$; Oshagbemi, 2000 ${ }^{128}$; Spector, $1997^{1251}$ ). Older workers find pleasure at work, show less turnover rates, and absenteeism (Naceur \& Fook, $2001^{1291}$ ).

As is the case with work experience, no evidence was found that job satisfaction increases with experience. The reason is that in the context of Pakistan, seeking job is the most difficult task as employment prevails over the country. Years after years no vacancies are advertised in teaching profession. The teachers who entered the profession have to continue it even they are not willing to do so. Substitute employment is scarce. There is no meaningful impact of teaching experience on job satisfaction factors in terms of pay, work, promotion, work conditions, and supervision variables. However, work group shows a significant difference. These findings are contrary to (Oshagbemi, 2000) ${ }^{1281}$, who claims that job satisfaction enhances with experience.

\section{PRACTICAL IMPLICATIONS}

The study offers practical suggestions to public sector educational institutions on how to recruit, pay, promote, and retain male and female teachers as well as to maintain gender equity in institutions. The government should provide more incentives to teachers, recruit teachers regularly and upgrade schools to balance with rapid growing of population.

\section{References}

[1] Koustelios, A. D. (2001). Personal characteristics and job satisfaction of Greek teachers. The International Journal of Educational Management, 15(7), 354-358.

[2] Chambers, J. (1999). The job satisfaction of managerial and executive women: Revisiting the assumptions. Journal of Education for Business, 75(2), 69-74.

[3] Mathieu, J. E. (1991). A cross-level nonrecursive model of the antecedents of organizational commitment and satisfaction. Journal of Applied Psychology, 76, 607-618. 
[4] Ostroff, C. (1992). The relationship between satisfaction, attitudes, and performance: An organizational level analysis. Journal of Applied Psychology, 77(6), 963-974.

[5] Mueller, C., Boyer, E., Price, J., \& Iverson, R. (1994). Employee attachment and noncoercive conditions of work: The case of dental hygienists. Work and Occupations, 21, 179-212.

[6] Price, J. L. (1997). Handbook of organizational measurement. Bradford, UK: MCB University Press.

[7] Akhtar, M. S. (1994). Job satisfaction in primary teachers. Bulletin of Education and Research, 16(1/2), 87-99.

[8] Akhtar, M. S. (2000). Job satisfaction and customer focus: A survey of elementary school teachers. Unpublished master's thesis, University of Michigan, USA.

[9] Akhtar, M. S. (2010). Job satisfaction and customer focus: A survey of elementary school teachers. Germany: VDM Verlag Dr. Muller Aktiengesellschaft \& Co.

[10] Zembylas, M., \& Papanastasiou, E. (2004). Job satisfaction among school teachers in Cyprus. Journal of Educational Administration, 42, 357-374.

[11] Lambert, E. G., Hogan, N. L., Barton, A., \& Lubbock, S. M. (2001). The impact of job satisfaction on turnover intent: A test of a structural measurement model using a national sample of workers. Social Science Journal, 38(2), $233-251$.

[12] Ma, X., \& MacMillan, R. (1999). Influences of workplace conditions on teachers' job satisfaction. Journal of Educational Research, 93(1), 39-47.

[13] Watson, A., Hatton, N., Squires, D., \& Soliman, I. (1991). School staffing and the quality of education: Teacher adjustment and satisfaction. Teaching and Teacher Education, 7, 63-77.

[14] Al-Mashaan, O. (2003). Associations among job satisfaction, pessimism, and psychosomatic symptoms of employees in the government sector. Psychological Reports, 93, 17-25.

[15] Clark, A., Oswald, A., \& Warr, P. (1996). Is job satisfaction U-shaped in age? Journal of Occupational and Organizational Psychology, 69, 57-81.

[16] Witt, L. A., \& Nye, L. G. (1992). Gender and relationship between perceived fairness of pay or promotion and job satisfaction. Journal of Applied Psychology, 77(6), 910-917.

[17] Kremer-Hayton, L., \& Goldstein, Z. (1990). The inner world of Israeli secondary school teachers: Work centrality, job satisfaction, and stress. Comparative Education, 20(2/3), 285-298.

[18] Cramer, D. (1993). Tenure, commitment, and satisfaction of college graduates in an engineering firm. Journal of Social Psychology, 133(6), 791-797.

[19] Robbins, S. P. (2003). Organizational behavior. New Jersey. Prentice-Hall.

[20] managerial stress in Hong Kong. Psychology and Aging, 16, 707-710.

[21] Staw, B. M. (1995). Psychological dimensions of organizational behavior. (2nd ed.). New Jersey: Prentice Hall.

[22] Tolbert, P. S., \& Moen, P. (1998). Men's and women's definitions of good jobs. Work \& Occupations, $25(2), 168-195$.

[23] Blood, G., Ridenour, J., Thomas, E., Qualls, C., \& Hammer, C. (2002). Predicting job satisfaction among speech-language pathologists working in public schools. Language, Speech and Hearing Services in Schools, 33, $282-290$.

[24] Ingersoll, R. M. (2001). Teacher turnover and teacher shortages. American Educational Research Journal, $38(3), 499-534$.

[25] Spector, P. E. (1997). Job satisfaction: Application, assessment, causes, and consequences. Thousand Oaks, CA: Sage.

[26] Begley, T., \& Czajka, J. (1993). Panel analysis of the moderating effects of commitment on satisfaction, intent to quit, and health following organizational change. Journal of Applied Psychology, 78, 552-556.

[27] Hodson, R. (1997). Group relations at work: Solidarity, conflict, and relations with management. Work \& Occupations, 24(4), 426-452.

[28] Oshagbemi, T. (2000). How satisfied are academics with their primary tasks of teaching research and administration and management? International Journal of Sustainable Higher Education, 1(2), 124-136.

[29] Naceur J., \& Fook, C. Y. (2001). Job satisfaction of secondary school teachers in Selangor, Malaysia. International Journal of Commerce and Management, 11(3/4), 72-90.

[30] Sari, H. (2004). An analysis of burnout and job satisfaction among Turkish special school headteachers and teachers, and the factors effecting their burnout and job satisfaction. Educational Studies, 30(3), 291-306.

[31] Brown, D. (2005). Job satisfaction and its relationship to organizational and religious commitment among workers at Northern Caribbean University. Unpublished doctoral dissertation, Andrews University, Berrien Springs, MI.

[32] Ruhl-Smith, C. D. (1991). Teacher attitudes toward students: Implications for job satisfaction in a sample of elementary teachers from suburban schools. Unpublished doctoral dissertation. Oxford, OH: Miami University.

[33] Tasnim, S. (2006). Job satisfaction among female teachers: A study on primary schools in Bangladesh. Unpublished M. Phil. dissertation, University of Bergen, Norway.

[34] Arnold, N. L., Seekins, T., \& Nelson, R. E. (1997). A comparison of vocational rehabilitation counselors: Rural and urban differences. Rehabilitation Counseling Bulletin, 41, 2-14.

[35] Finley, W. H. (1991). High school principals' job satisfaction. Unpublished doctoral dissertation, Memphis State University, Memphis, Tennessee.

[36] Worrell, T. G. (2004). School psychologists' job satisfaction: Ten years later. Unpublished doctoral dissertation, Blacksburg, Virginia.

[37] Saeed, M. (1997). Job satisfaction among Pakistani secondary and higher secondary school teachers in comparison to other international countries. Bulletin of Education and Research, 2, 37-58. 